\title{
ПОКАЗАТЕЛЬ НАРУШЕННОСТИ ЕСТЕСТВЕННОГО РЕЖИМА ГРУНТОВЫХ ВОД
}

\section{А.М.Бондаренко \\ Саратовский государственный университет, кафедра геоморфологии и геоэкологии \\ E-mail: bam54@list.ru}

На основе использования многолетней информации о динамике уровней грунтовых вод предлагается статистический критерий изменчивости естественного режима грунтовых вод на урбанизированных территориях. Предлагаемый показатель целесообразно применять для построения карты нарушенности природного режима уровня грунтовых вод при моделировании потенциальной подтопляемости территорий.

\section{Environmental Disturbance of Ground Water Natural Circulation Mode}

\section{A.M. Bondarenko}

Based on multi-year data about the changes in the ground water level a statistical criterion for the variability of ground water natural circulation mode in the urban lands in offered in this article. It is expedient to use the suggested value of environmental disturbance for making an inundation map of level environmental disturbance when simulating the land potential ground water inundation (waterlog).

Одним из отрицательных последствий инженерно-хозяйственной деятельности является подъем уровня грунтовых вод (УГВ) на урбанизированных территориях вследствие изменения водного баланса грунтовых вод. При подъеме УГВ, достигающем уровня выше критического, происходит подтопление зданий и сооружений, что приводит к изменению прочностных и деформационных свойств оснований фундаментов.

Для решения проблем, связанных с появлением и развитием подтопления, необходимо своевременное изучение комплекса данных природного и техногенного характера. При этом подвергаются анализу физико-географические условия, геологическое строение территории, наблюдения за УГВ на режимных скважинах, инженерное устройство территории, условия застройки и другие данные.

Далее необходимо выявить естественные и искусственные факторы и источники подтопления [1], которые учитываются при математическом моделировании потенциальной подтопляемости территории. Нарушение естественного режима грунтовых вод вызывается различными причинами, в разной степени влияющими на развитие подтопления. Степень нарушенности естественных колебаний УГВ обусловлена различной застройкой города (от индивидуальной до многоэтажной), неравномерным распределением водонесущих

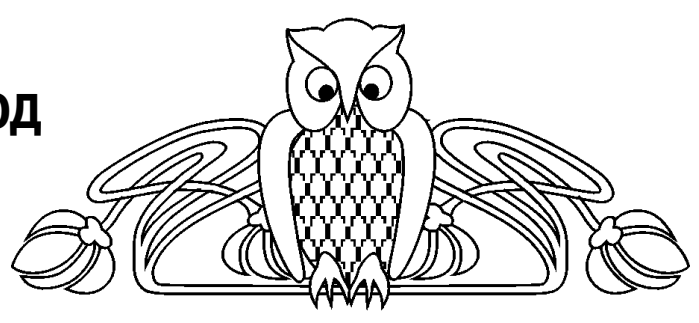

коммуникаций и соответственно пространственной и временной непредсказуемостью утечек из них, различной дренированностью территории. Иногда выявляется зависимость степени нарушенности от условий застройки территории, и это учитывается при соответствующем районировании. Однако тип застройки далеко не всегда является определяющим фактором степени нарушенности режима грунтовых вод.

При оценке потенциальной подтопляемости наряду с приемами качественного анализа ситуации необходимо использовать количественный показатель (критерий) нарушенности, который позволил бы объективнее оценивать степень изменения режима грунтовых вод как в селитебной, так и в промышленной зонах.

Предлагаемый показатель нарушенности основывается на использовании многолетней информации о динамике уровней грунтовых вод. При этом анализу подвергаются все среднегодовые гидрографы, построенные по данным наблюдений на режимных гидрогеологических скважинах.

Фактическим материалом, определяющим степень нарушенности естественного режима, является не столько ряд значений среднегодовых УГВ, сколько ряд изменений (среднегодовых разностей), смежных в многолетнем ряду наблюдений:

$$
\Delta H_{i}=H_{i+1}-H_{i} .
$$

Характер изменчивости этих величин от года к году хорошо отражает влияние именно неприродных факторов подтопления. К тому же величина $\Delta H_{50 \%}$, т. е. наиболее вероятной 50\%-ной обеспеченности, дает приближенное представление о таком трудноопределимом параметре, как модуль грунтового питания в разных районах подтапливаемой территории.

Степень нарушенности режима УГВ находит свое отображение и во внутрирядной корреляции составляющих ряда разностей $\Delta H_{i}$. В качестве характеристики при этом может быть применен коэффициент корреляции между разностями среднегодовых уровней смежных лет $-r_{i, i+1}$. В том случае, если нарушенность естественного режима грунтовых вод имеет систематический (не случайный) характер, этот коэффициент возрастает. В природных ненарушенных условиях залегания 
Сопоставление показателелей нарушенности и динамики УГВ в черте города с показателями и графиками естественных изменений уровня за пределами города в аналогичных физикогеографических условиях позволяет судить о приемлемости подобной типизации [3].

Точность выделения границ районов с применением показателя $N_{r}$ зависит от равномерности и густоты использованной режимной сети скважин, т. е. от степени гидрогеологической изученности рассматриваемой территории.

Применение количественного критерия для оценки степени нарушенности уровенного режима грунтовых вод позволяет объективнее и с большей достоверностью выявить факторы и источники подтопления. Кроме того, предлагаемый статистический критерий дает возможность математически формализовать районирование территории по степени нарушенности режима УГВ при использовании геоинформационных систем.

Карту нарушенности естественного режима УГВ, полученную на основе показателя нарушенности, целесообразно применять при моделировании потенциальной подтопляемости территории по соответствующим геофильтрационным схемам. При этом на разных этапах комплексного изучения подтопляемости грунтовыми водами строятся либо обновляются также и карты литологических комплексов, кровли водоупора, гидроизогипс, карты инженерного устройства, условий застройки.

\section{Библиографический список}

1. Абрамов С.К., Дегтярев Б.М., Дзекиер Е.С. и др. Прогноз и предотвращение подтопления грунтовыми водами территории при строительстве. М., 1978. 151с.

2. Рождественский А.В., Чеботарев А.И. Статистические методы в гидрологии. Л., 1974. 424 с.

3. Бондаренко А.М., Мамаева С.А. Опыт комплексного изучения подтопляемости г. Павлодара грунтовыми водами // Инженерная геология. М., 1987, Вып. 5. С.78-83. $\geq 0.05 \mathrm{M}$.

$01 \mathrm{M}$

- тип нарушенного режима $-0,01 \leq N_{r}>$ $>0.05 \mathrm{M}$,

- тип весьма нарушенного режима $-N_{r} \geq$ УДК 528.94:55(470.44)

\section{НА ГЕОГРАФИЧЕСКОМ ФАКУЛЬТЕТЕ САРАТОВСКОГО УНИВЕРСИТЕТА}

ОПЫТ СОЗДАНИЯ ГЕОИНФОРМАЦИОННЫХ СИСТЕМ

\author{
В.3. Макаров, А.Н. Чумаченко, А.М. Дёмин, В.А. Гусев, \\ А.В. Федоров, Ю.В. Волков, В.А. Данилов, А.С. Панкратьев
}

Саратовский государственный университет, лаборатории урбоэкологии и регионального анализа, геоинформатики и тематического картографирования E-mail: gis@sgu.ru

В статье приводятся результаты многолетних работ по созданию многоцелевых и проблемно-ориентированных гео-

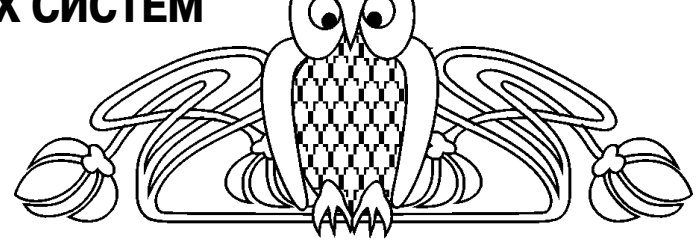

графических информационных систем (ГИС), выполненных в научно-исследовательских лабораториях географического факультета Саратовского государственного университета имени Н.Г. Чернышевского. Подробно рассмотрены структура и содержание комплексной муниципальной ГИС, специализированных ГИС по градоэкологии, ГИС по управлению национальным парком. 